\title{
PKM Coping Stress Pada Mahasiswa
}

\author{
Muhammad Nur Hidayat Nurdin ${ }^{1}$, Nurfitriany Fakhri ${ }^{2}$ \\ ${ }^{1,2}$ Fakultas Psikologi, Universitas Negeri Makassar
}

\begin{abstract}
This PKM activity aims to transfer of knowledge in the form of knowledge about stress, stress triggers, stress coping, types of coping, and steps of coping behavior. This activity was carried out in the campus hall involving 50 college students, namely STAI-DDI students, Tangnga Pangkep Regency. The methods used are brain storming, short film screening, material delivery by lecturing, discussion and sharing experiences. The result of this activity is the absorption of material about stress and stress coping by the participants (partners), which in turn can be used to deal with the stress they feel.
\end{abstract}

Keywords: Stress, Stress Coping

\section{PENDAHULUAN}

Manusia yang kemudian disebut sebagai individu adalah makhluk ciptaan Tuhan Yang Maha Kuasa yang dibekali kemampuan untuk menyesuaikan diri dengan lingkungannya, terutama lingkungan yang baru ditempatinya. Proses penyesuaian diri ini terkait dengan semua kepentingan individu untuk keberlangsungan hidupnya dalam lingkungannya, baik kepentingan fisik, psikologis, maupun kepentingan untuk berperilaku. Proses penyesuaian diri diperlukan untuk menyelaraskan antara tuntutan lingkungan yang baru, dengan hajat individu yang mendiami lingkungan tersebut.

Persoalan yang muncul kemudian adalah bahwa proses penyesuaian yang dilakukan oleh individu seringkali tidak berjalan sesuai dengan apa yang direncanakan oleh individu. Terhambatnya proses penyesuaian diri dapat menyebabkan terjadinya stres pada individu. Tidak terkecuali pada mahasiswa yang baru memasuki lingkungan yang baru, dalam hal ini kampus. Dunia kampus adalah dunia yang secara kultural maupun sosial relatif berbeda dengan dunia pendidikan sebelumnya (sekolah menengah). Kampus menghimpun berbagai karakter dan kepentingan mahasiswa yang menimba ilmu di dalamnya. Kehidupan kampus yang lebih terbuka dan dinamis memungkinkan terjadinya pembauran berbagai latar belakang mahasiswa. Kondisi ini jika tidak disikapi secara bijaksana oleh mahasiswa dapat mengarahkannya pada kondisi stress, yang bukan tidak mungkin dapat menghambat proses belajarnya dalam perkuliahan.

Stres pada level tertentu dapat menjadi alarm reaction (Selye; dalam Davison, Kring \& Neale, 2006) yang dengannya manusia dapat mengembangkan cara-cara tertentu untuk keluar dari masalahnya, hingga akhirnya dapat menghantarkan manusia untuk dapat hidup lebih sehat. Sebaliknya, stres yang tidak tertangani secara serius dapat mengarahkan individu ke dalam kondisi yang lebih menyedihkan. Stres yang terus menerus dibiarkan tanpa penanganan bahkan dapat mengarahkan seseorang nekat melakukan aksi bunuh diri, sebagai manivestasi ketidakberdayaan manusia yang paling rendah. Contoh yang paling dekat dalam kehidupan remaja adalah kematian artis-artis idola mereka, yang setelah ditelusuri ternyata berawal dari stres yang tidak tertangani dengan baik dan cepat.

Apa sesungguhnya stres itu? Mengapa stres seringkali bagi sementara individu dianggap sebagai kondisi yang sangat menakutkan? Mengapa banyak yang akhirnya tidak berdaya mengatasinya? Looker dan Gregson (2005) menjelaskan bahwa stres merupakan suatu kondisi yang dialami oleh individu yang ditandai dengan adanya ketidaksesuaian antara tuntutan-tuntutan yang diterima dari lingkungan, dibandingkan dengan kemampuan yang dimiliki untuk 
mengantisipasi tuntutan-tuntutan tersebut. Sapuri (2009) mendefinisikan stres sebagai keadaan yang terkait erat dengan kendala dan tuntutan dari lingkungan. Kendall dan Hammen (Safaria \& Saputra, 2009) mendefinisikan stres relatif sama dengan pengertian sebelumnya, yakni bahwa stres dapat dialami individu ketika terdapat ketidakseimbangan antara kondisi yang menuntut dan perhitungan individu terhadap kemampuannya dalam mengatasi tuntutan yang ada. Stres tidak jarang menjadi kondisi yang menakutkan bagi indvidu, karena ternyata tidak semua dari individu yang memiliki kapasitas yang cukup untuk menjawab tuntutan lingkungan yang datang kepadanya. Selye (Davison, Neale \& Kring, 2006) yang juga diikuti oleh beberapa peneliti menegaskan bahwa stres merupakan respon terhadap berbagai tuntutan lingkungan.

Hasil-hasil riset menjelaskan tentang sumbersumber utama sehingga individu dapat mengalami stres. Beberapa diantaranya stres yang bersumber dari sekolah, pekerjaan, keluarga, masalah hukum, finansial, dan sebagainya. Stres yang bersumber dari masalah sekolah misalnya dapat disebabkan oleh materi pelajaran yang mungkin dianggap terlalu berat, tugas-tugas yang tidak ringan baik dari segi jumlah maupun bobotnya, hubungan dengan seluruh komponen yang ada di kampus, atau bahkan tuntutan dari orangtua tentang bagaimana prestasi akademik yang harus diraih oleh mahasiswa. Stres yang bersumber dari pekerjaan dapat dijumpai misalnya pada tidak berimbangnya antara beban kerja dan upah yang diterima, beban kerja yang berat dan mendesak untuk diselesaikan dalam waktu singkat (Iskandar, 2012), jenis pekerjaan yang ternyata tidak sesuai dengan bakat dan keahlian, lingkungan kerja yang sarat stresor kerja (seperti akibat suara mesin, kesesakan, atau hubungan dengan rekan kerja yang sulit), aturan cuti untuk kepentingan tertentu, hubungan dengan atasan yang tidak harmonis, dan sebagainya.

Kondisi perpindahan atau perubahan yang dialami oleh individu, atau dalam hal ini mahasiswa dapat menjadi sumber stres. Perubahan status dari siswa menjadi mahasiswa memberi konsekuensi kian kompleksnya tantangan yang akan dihadapi oleh mahasiswa. Perbedaanperbedaan mendasar yang menjadi jarak antara masa sekolah menengah dengan kehidupan kampus, jika tidak disikapi dengan baik dapat mengarahkan mahasiswa pada kondisi stres. Stres yang dialami mahasiswa dapat berbentuk stress akademik. Stres yang banyak dialami mahasiswa adalah stres akademik. Jun dan Choi (Kasim, Murdiana \& Fakhri, 2018) menyatakan bahwa stres akademik adalah tekanan yang bersumber dari tuntutan tugas akademik. Hong (Kasim, Murdiana \& Fakhri, 2018) menemukkan beberapa masalah yang dapat ditimbulkan oleh stres akademik yaitu berbagai masalah psikologis seperti kecemasan, depresi, bahkan gangguan tidur. Faktor yang menyebabkan stres akademik dapat ditimbulkan dari pengajar, usaha dalam mencapai prestasi, ujian, kegiatan belajar kelompok, teman, manajemen waktu, dan dari dalam diri sendiri (Lin \& Chen dalam Kasim, Murdiana \& Fakhri, 2018).

Perbedaan-perbedaan yang dimaksud misalnya dari segi kurikulum pembelajaran yang praktis sangat berbeda dengan yang pernah dijumpai oleh mahasiswa di sekolah menengah. Sistem pembelajaran di perguruan tinggi dilakukan dengan sistem Satuan Kredit Semester (SKS) yang memungkinkan mahasiswa memilih secara mandiri mata kuliah apa saja yang ingin deprogram di setiap semesternya, kecuali untuk mata kuliah wajib. Selain itu, jumlah mata kuliah yang dapat diprogram oleh mahasiswa setiap semesternya sangat mungkin berbeda antara mahasiswa satu dengan yang lainnya. Hal ini disebabkan besaran Indeks Prestasi Semester (IPS) dan Indeks Prestasi Kumulatif (IPK) yang diraih oleh masing-masing mahasiswa berbeda-beda. IPS dan IPK menjadi dasar bagi mahasiswa untuk menentukan berapa banyak mata kuliah yang dapat diprogramnya di semester depan.

Hal berbeda yang dijumpai saat masih di sekolah menengah adalah bahwa pola pembelajaran yang dilakukan oleh setiap siswa sudah terstandar dan telah ditetapkan oleh sekolah. Mata pelajaran yang akan ditempuh oleh setiap siswa pada semester berikutnya telah ditetapkan. 
Selain itu jam belajar juga telah ditetapkan oleh pihak sekolah, yang pada umumnya dimulai pada pukul 07.00 sampai selesai, sementara jadwal kuliah dapat diatur secara fleksibel oleh setiap mahasiswa, sesuai dengan kebutuhannya.

Kondisi lain yang menjadi diferensiasi antara dunia kampus dan sekolah menengah yang juga potensial menimbulkan stres adalah jumlah maupun bobot tugas yang harus diselesaikan oleh setiap mahasiswa. Tidak jarang setiap mata kuliah memiliki tugasnya masing-masing, dan seringkali tidak hanya satu tugas untuk setiap mata kuliah. Suatu mata kuliah terkadang memberi beban tugas lebih dari satu kepada mahasiswa, dengan durasi waktu yang relatif singkat, mengingat mahasiswa diharuskan menyelesaikan tugas-tugas dari beberapa mata kuliah sekaligus.

Berbagai hal di lingkungan kita sehari-hari masing-masing memiliki potensi untuk memicu terjadinya stres pada individu. Fakta ini membawa isyarat bahwa stres sebagai efek yang seringkali muncul dari suatu masalah itu sesungguhnya dapat saja menjadi sebuah keniscayaan yang harus ditanggung oleh individu, tetapi fakta bahwa individu memiliki kapasitas penyesuaian diri dalam lingkungan juga tidak dapat diabaikan. Individu telah dibekali kemampuan oleh Tuhan YME untuk mengentaskan dirinya dari kondisi yang tidak menyenangkan, seperti stres. Strategi atau cara yang dikembangkan oleh individu untuk menghadapi stresnya disebut dengan coping stress.

Lazarus dan Folkman (dalam Hendriani, 2018) menjelaskan koping sebagai kiat yang dikembangkan oleh individu untuk mengelola kognisi dan perilakunya secara konstan, untuk mengatasi berbagai kondisi internal maupun eksternal yang berubah. Kondisi berpindah dari masa SMU kepada kehidupan kampus merupakan sebuah perubahan signifikan pada individu yang beralih status dari siswa menjadi mahasiswa. Setiap perubahan pada akhirnya dapat berdampak pada kondisi stres, dan oleh karena itulah individu atau mahasiswa perlu mengembangkan strategi koping.

Oleh karena itu dipandang perlu membekali mahasiswa, terutama yang baru saja menempuh jenjang pendidikan di perguruan tinggi sebuah kemampuan untuk mengatasi stres yang dirasakannya akibat beban yang diperolehnya dari perkuliahan. Kemampuan yang dimaksud adalah strategi koping (coping stress), yang jika dipraktikkan dengan baik dapat membantu mahasiswa keluar dari kondisi stresnya.

\section{METODE PELAKSANAAN}

Peserta yang dilibatkan dalam kegiatan PKM ini adalah mahasiswa baru yang berasal dari beberapa jurusan dalam lingkup Sekolah Tinggi Agama Islam Darud Dakwah wal Irsyad (STAI-DDI) Baru-Baru Tangnga, Kabupaten Pangkep, yang berjumlah sekitar 50 orang. Bahkan saat pelaksanaan kegiatan terdapat beberapa dosen dari lokasi mitra yang menyempatkan hadir sebagai peserta. Adapun luaran yang menjadi tujuan dari kegiatan ini adalah bahwa mitra dalam hal ini mahasiswa STAI-DDI Baru-Baru Tangnga Kabupaten Pangkep, dapat memperoleh bekal pengetahuan dan pengalaman tentang stres dan koping stres. Diharapkan bahwa setelah memperoleh materi tersebut, mahasiswa tidak lagi perlu merasa cemas ketika mengalami stres, sebab mereka telah memiliki pengetahuan tentang bagaimana agar dapat segera keluar dari kondisi yang menyebabkan stres.

Pelaksanaan program kemitraan Masyarakat (PKM) ini disesuaikan dengan kebutuhan mitra, dan kondisi yang ada di lapangan. Berdasarkan informasi yang tim pelaksana peroleh bahwa mahasiswa berasal dari berbagai daerah maupun latar belakang sosial, bahkan ada yang berasal dari luar pulau dan luar kabupaten. Perubahan atau perpindahan suasana maupun kondisi wilayah dari yang sebelumnya diakrabi kemudian menjadi asing, merupakan salah satu kondisi yang rentan untuk memicu terjadinya stres. Berada jauh dari keluarga, tugas-tugas keseharian yang sangat menuntut kemandirian (makan, cuci pakaian dilakukan secara mandiri), keharusan mengakrabi orang-orang baru dari berbagai latar belakang budaya, materi pelajaran yang barangkali belum pernah dijumpai sebelumnya, dan masih banyak contoh masalah lain yang melingkupi kehidupan para mahasiswa adalah beragam contoh faktor 
penyebab terjadinya stres pada mahasiswa.

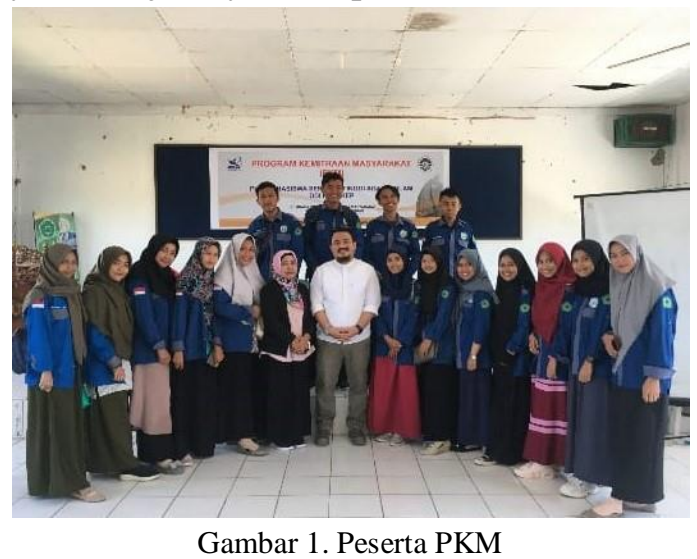

Metode yang digunakan dalam kegiatan PKM ini terdiri atas beberapa kegiatan, yaitu brain storming, ceramah, pemutaran film, pemberian games untuk sesi ice breaking, dan diskusi (sharing) tentang pengalaman mitra selama menjadi mahasiswa. Secara teknis, peserta dikumpulkan dalam sebuah ruangan yang telah disiapkan lalu diberikan ceramah mengenai materi yang menjadi topik kegiatan PKM ini. Mengawali kegiatan dilakukan brain storming, kemudian peserta disuguhkan film berdurasi singkat yang bertujuan untuk memantik minat mitra, lalu pemateri memberi pengantar tentang pengertian umum dari stres, faktor-faktor penyebabnya, dan materi terkait koping stres. Setelah materi dalam bentuk ceramah tuntas diberikan, kegiatan dilanjutkan dengan pemberian beberapa permainan (games) yang bertujuan untuk mencairkan suasana, dan agar peserta tidak merasa cemas.

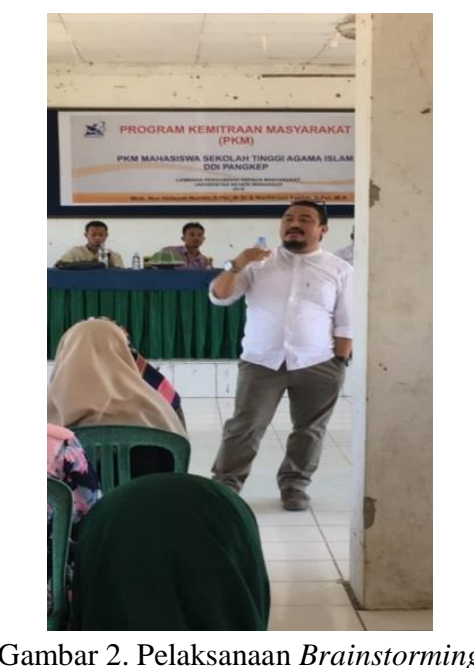

PKM Coping Stress Pada Mahasiswa.

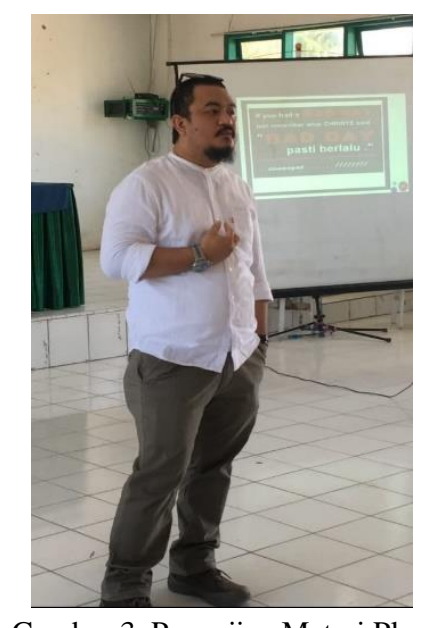

Gambar 3. Penyajian Materi Pkm

Setelah games dilanjutkan dengan sesi diskusi dan tanya jawab seputar materi yang telah diberikan. Di bagian akhir kegiatan ini para peserta diajak untuk berkontemplasi dan merefleksi eksistensi mereka sebagai mahasiswa. Diskusi dimungkinkan untuk dilakukan di tengah-tengah penyampaian materi ceramah, jika mitra memang merasa ada yang perlu untuk didiskusikan.

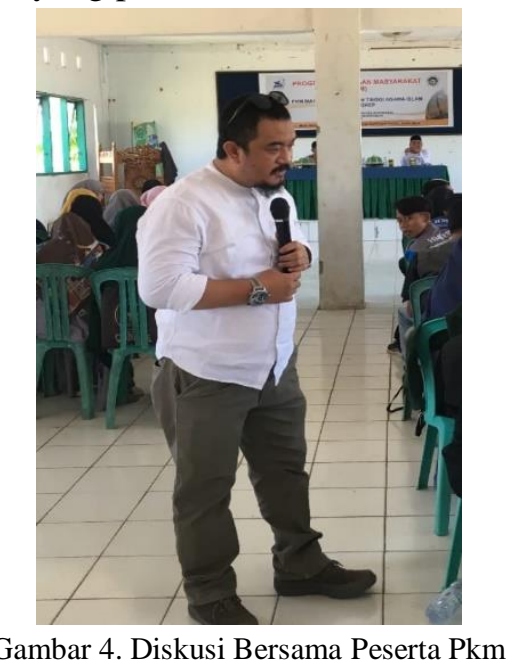

Proses penyajian materi dapat berjalan dengan lancar. Beberapa perangkat pengantar seperti pengenalan tim pelaksana, brain storming, dan pemutaran film berdurasi singkat dapat berjalan sesuai rencana. Saat penyajian materi juga diikuti dan disimak dengan penuh perhatian dan antusiasme dari mitra. Saat diskusi (sharing) dilakukan, tampak mitra sangat antusias ingin mengajukan pertanyaan dan berbagi cerita dengan mitra lainnya. Beberapa dosen juga tampak turut berpartisipasi sebagai peserta dalam sesi penyajian 
materi, termasuk memberi pertanyaan dan berbagi pengalaman dalam menghadapi mahasiswa.

\section{HASIL DAN PEMBAHASAN}

Secara umum kegiatan pengabdian (PKM) ini telah terselenggara dengan lancar dan sesuai dengan perencanaan, meski masih terdapat beberapa hal yang menjadi catatan bagi tim pelaksana sebagai evaluasi bagi tim untuk pelaksanaan kegiatan serupa di masa yang akan datang. Sejak awal dimulainya kegiatan, para peserta (mitra) menunjukkan antusiasme terhadap materi yang disajikan oleh tim pelaksana. Hal lain yang juga menarik perhatian peserta (mitra) adalah pada saat pemberian permainan (games). Beberapa kesimpulan terkait sesi games misalnya, bahwa ternyata para peserta memang amat sangat jarang (jika tidak boleh menyebut tidak pernah) mendapatkan kegiatan-kegiatan yang berisi permainan-permainan yang dapat melibatkan mereka secara berkelompok, yang justru dapat mencairkan suasana.

Setelah pemberian permainan (games) peserta kemudian diberi feedback terkait permainan yang telah mereka ikuti, dan dari sana para peserta kemudian mendapatkan gambaran utuh tentang muatan dari permainan tersebut. Pada sesi berikutnya peserta diberi materi dalam bentuk ceramah tentang stress dan coping stress dari tim pelaksana. Pada bagian akhir sesi tersebut, dilakukan diskusi terkait materi yang telah disampaikan dalam sesi ceramah. Beberapa pertanyaan muncul dari peserta, termasuk dari dosen yang juga turut menjadi peserta dalam kegiatan ini. Selain bertanya, sang dosen juga berbagi cerita dan pengalaman selama menjadi tenaga edukasi di STAI-DDI Baru-Baru Tangnga Kabupaten Pangkep. Suka duka dalam mengarahkan mahasiswa, pengalaman saat memberikan tugas, dan bagaimana menghadapi mahasiswa yang dianggap perilakunya belum sesuai.

Secara umum, hasil yang diperoleh dari kegiatan ini adalah bertambahnya pemahaman dan pengetahuan peserta (mitra) tentang stres, faktorfaktor yang dapat memicu terjadinya stres, dan hal- hal yang dapat dilakukan untuk mengatasi stres yang dirasakan (coping stress). Seluruh peserta (mitra) dalam kegiatan ini menyatakan rasa senang dan puas dengan pelaksanaan kegiatan PKM seperti ini, karena dapat memberikan wawasan dan pengetahuan yang baru bagi mereka. Para peserta (mitra) menyampaikan agar kegiatan serupa dapat terus dilakukan dengan materi-materi dan muatanmuatan psikologis yang lebih bervariasi (disesuaikan dengan kebutuhan), karena peserta merasa bahwa apa yang mereka peroleh dari kegiatan ini sangat up to date (kekinian) dan benarbenar sesuai dengan kebutuhan mereka.

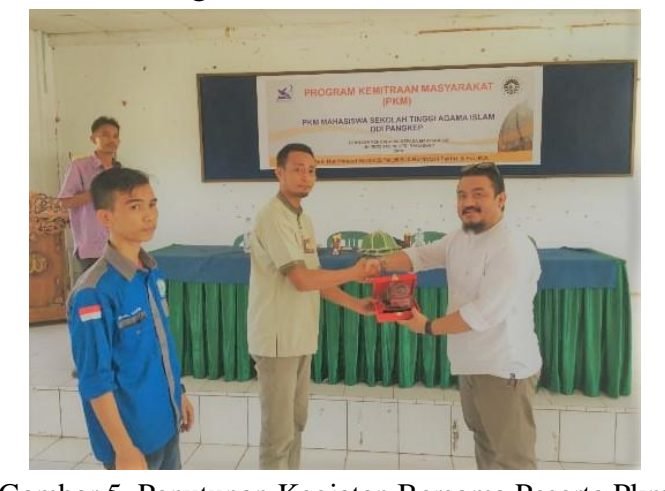

Gambar 5. Penutupan Kegiatan Bersama Peserta Pkm

Stres pada dasarnya bersifat alamiah dan dapat dirasakan oleh setiap orang. Pada batas tertentu, stres sesungguhnya tidak membahayakan sepanjang dapat ditangani dengan baik. Menurut Hans Selye (dalam Hanurawan, 2010) stress adalah reaksi organisme atau individu terhadap stimulus yang tidak menyenangkan. Veitch dan Arkkelin (dalam Hanurawan, 2010) mengemukakan bahwa stress adalah relasi interaktif yang terjadi di antara sistem fisik, fisiologis, psikologis, serta perilaku. Selye menjelaskan bahwa terdapat tiga adapatasi terhadap stress; 1) Alarm (peringatan); 2) Resistance (perlawanan); dan 3) Exhaustion (kelelahan). Apabila proses adaptasi tidak berlangsung sebagaimana seharusnya, maka individu dapat mengalami gangguan pada kesehatan fisik maupun gangguan kesehatan mental yang serius.

Beberapa sumber stres dapat dijelaskan pada bagian ini yaitu: 1) stressor fisik biologik (misalnya dapat disebabkan oleh penyakit fisik); 2) stressor psikologik (misalnya dapat disebabkan oleh 
perasaan cemburu, iri hati, atau angan-angan yang tidak tercapai); dan 3) stressor sosial (misalnya dapat disebabkan ketidakharmonisan dalam keluarga, pengangguran, atau lingkungan sosial yang berbeda dengan yang diakrabi selama ini).

Menurut Lazarus (dalam Hendriani, 2018) stres psikologis (psychological stress) terjadi saat individu menjumpai kondisi lingkungan yang sarat dengan tekanan, yang dinilai sebagai ancaman besar dan dianggap melampaui daya kopingnya. Lazarus menjelaskan terdapat 2 (dua) komponen utama dalam stres psikologis, yaitu: 1) Appraisal: yang menjelaskan tentang penilaian individu terhadap hal-hal penting yang terjadi dan memengaruhi well being-nya; dan 2) coping: terkait kiat-kiat yang dikembangkan individu secara kognitif maupun motorik yang bertujuan untuk mengelola tuntutan atau perubahan yang terjadi.

Secara khusus dapat dijelaskan pula tentang koping. Lazarus dan Folkman (Hendriani, 2018) mengartikan koping sebagai upaya yang dilakukan oleh individu dalam mengelola kognisi dan perilakunya secara konstan, dalam rangka mengantisipasi berbagai tuntutan (internal maupun eksternal) perubahan. Lazarus dan Folkman (Hendriani, 2018) juga menjelaskan dua tipe strategi koping, yaitu; 1) problem-focused coping (PFC): yakni upaya dengan melakukan aktivitas tertentu untuk menghilangkan keadaan yang memicu terjadinya stres; dan 2) emotion-focused coping (EFC): kiat yang dialkukan individu untuk mengontrol konsekuensi emosional dari peristiwa yang menjadi pemicu stress, atau kondisi yang potensial menimbulkan stres. Beberapa faktor yang memengaruhi perilaku koping antara lain adalah: 1) kemampuan menerka; 2) kontrol atas jangka waktu; 3) evaluasi kognitif; 4) perasaan sanggup/ mampu; dan 5) dukungan masyarakat atau keluarga.

\section{DAFTAR PUSTAKA}

Davison, G. C., Neale, J. M., \& Kring, A. M. (2006). Psikologi Abnormal (Edisi ke-9). Jakarta. PT RajaGrafindo Persada
Hanurawan, F. (2010). Psikologi Sosial: Suatu Pengantar. Bandung. PT. Remaja Rosdakarya

Hendriani, W. (2018). Resiliensi Psikologis: Suatu Pengantar. Jakarta. Prenada Media Grup

Iskandar, Tb. Z. (2012). Psikologi Lingkungan: Teori dan Konsep. Editor: Nurul Falah Atif. Bandung. PT. Refika Aditama.

Kasim, M. I., Murdiana, S., \& Fakhri, N. (2018). Pengaruh Stres Akademik Dan Kecanduan Internet Dengan Kualitas Tidur Pada Mahasiswa Di Kota Makassar. Proceedings of Psychology" Cyber Effect: Internet Influence on Human Life", 83-95.

Looker, T., \& Gregson, O. (2004). Managing Stres: Mengatasi Stres Secara Mandiri. (Alih bahasa: Haris Setiawan). Yogyakarta. Penerbit BACA!

Safaria, T., \& Saputra, N. E. (2009). Manajemen Emosi: sebuah Panduan Cerdas Bagaimana Mengelola Emosi Positif dalam Hidup Anda. Jakarta. PT Bumi Aksara

Sapuri, R. (2009). Psikologi Islam: Tuntutan Jiwa Manusia Modern. Jakarta. PT RajaGrafindo Perkasa 